\title{
PROTOPLAST PRODUCTION FROM NAPIER GRASS AND PEARL MILLET TRIPLOID HYBRIDS
}

\section{Obtenção de protoplastos de híbridos triplóides entre o capim-elefante e milheto}

\author{
Ana Luiza de Oliveira Timbón ${ }^{1}$ Lisete Chamma Davide², \\ José Eduardo Brasil Pereira Pinto ${ }^{3}$, Antônio Vander Pereira ${ }^{4}$
}

\begin{abstract}
The objective of this work was to obtain protoplasts from napier grass and pearl millet triploid hybrids as a basis for future studies on chromosomal duplication. Explants were taken from mesophyll of in vitro- and in vivo-cultured plants or from calli of two triploid hybrids ( $\mathrm{H} 1$ and $\mathrm{H} 2)$, which were treated with enzymatic solutions containing different concentrations of cellulase R-10 (0.5, $1.0,1.5$ and $2.0 \%$ ) with an additional $0.2 \%$ macerozyme and $0.1 \%$ driselase or $1.0 \%$ pectolyase Y-23 and $0.5 \%$ hemicellulase. Enzymatic digestion was monitored once every hour for five hours. Protoplasts were obtained from in vitro and in vivo leaflets of both triploid hybrids, and in vitro leaflets were the best explant sources. The quantity of produced protoplasts varied according to the hybrid, the enzymatic solution and the treatment time.
\end{abstract}

Index terms: Pennisetum purpureum, Pennisetum glaucum, In vitro cultivation, Interspecific hybrids, Forage.

\section{RESUMO}

Objetivou-se, neste trabalho, a obtenção de protoplastos de híbridos triplóides entre o capim-elefante e o milheto como base para futuros trabalhos de duplicação cromossômica. Foram utilizados explantes de mesofilo de plantas cultivadas in vitro e in vivo, ou de calos de dois híbridos triplóides (H1 e H2), os quais foram tratados com soluções enzimáticas em diferentes concentrações da enzima celulase R-10 $(0,5 ; 1,0 ; 1,5$ e $2,0 \%)$, acrescidas de $0,2 \%$ macerozyme e $0,1 \%$ driselase ou $1,0 \%$ pectolyase $\mathrm{Y}-23$ e $0,5 \%$ hemicelulase. A digestão enzimática foi monitorada a cada hora durante 5 horas. Obtiveram-se protoplastos a partir de folhas in vitro e in vivo dos dois híbridos triplóides, sendo as folhas in vitro as melhores fontes de explante. A quantidade de protoplastos variou em função do híbrido, da solução enzimática e do tempo de tratamento.

Termos para indexação: Pennisetum purpureum, Pennisetum glaucum, cultivo in vitro, híbridos interespecíficos, forrageiras.

\section{(Received in september 11, 2008 and approved in may 14, 2009)}

\section{INTRODUCTION}

Napier grass is largely used to feed the livestock, especially cattle, sheep and goats. It also has great energetic potential for charcoal, bio-oil and biogas production, as well as for electricity in thermoelectric power plants and rural properties. In addition, short and purple cultivars can be employed in landscaping (Pereira et al., 2001; Mesa-Perez et al., 2005; Strezov et al., 2008).

In Brazil, napier grass is mainly used as forage, and although it is grown all over the country, there is a demand for improved cultivars that could better adapt to different edaphic-climatic conditions and utilization systems, due to the few existent plant breeding programs (Pereira et al., 2001).

Most of napier grass characteristics of forage importance can be improved by exploiting the variability within the species. However, based on the capability of this grass to exchange alleles with other Pennisetum Rich. species, the plant breeding program can use germplasm from species belonging to close genic groups like pearl millet (Pereira et al., 2001). This type of genetic combination tries to gather in the hybrid some of the desirable characteristics of pearl millet such as vigor, drought resistance, disease tolerance, forage quality and seeds size, whereas rusticity, aggressiveness, perennity, palatability and high dry matter yield are provided by napier grass (Schank et al., 1996; Jauhar \& Hanna, 1998; Souza Sobrinho et al., 2008).

However, these two species have different ploidy levels: napier grass is allotetraploid $(2 \mathrm{n}=4 \mathrm{x}=28$, genomes

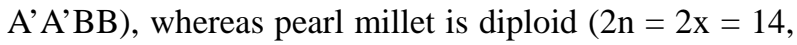
genome AA). Hybridization between them produces an infertile triploid hybrid $(2 \mathrm{n}=3 \mathrm{x}=21$ chromosomes, genomes AA'B) and such infertility is the main barrier in

\footnotetext{
1Universidade Federal de Lavras/UFLA - Post office box 37 - Lavras, MG - 37200-000 - Scholarship holder of the Capes - oliveiratal@ yahoo.com.br 2Universidade Federal de Lavras/UFLA - Department of the Biology - Lavras, MG

${ }^{3}$ Universidade Federal de Lavras/UFLA - Department of the Agriculture - Lavras, MG

${ }^{4}$ Embrapa Gado de Leite - Juiz de Fora, MG
} 
breeding programs, hindering its utilization in crossings and its propagation through seeds.

Fertility can be restored by chromosomal duplication using antimitotics (Hanna, 1981; Hanna et al., 1984; Abreu et al., 2006; Barbosa et al., 2007). Barbosa et al. (2007) induced chromosomal duplication in buds and shootings. However, when multicellular vegetative material was used in vitro, this duplication process resulted in the production of mostly mixoploid and a few stable hexaploid plants.

The utilization of protoplasts either for treatment with antimitotics (Zeng et al., 2006) or for fusion could help overcome the mixoploidy problem, producing stable hexaploid plants. Another advantage is that hybrids can be mass-produced after the protocol is optimized.

Thus, the aim of the current work was to develop a methodology for protoplast production from napier grass and pearl millet triploid hybrids as a basis for future studies on hybrid chromosomal duplication through both protoplasts fusion for allohexaploids formation and antimitotic treatment for autohexaploids formation.

\section{MATERIAL AND METHODS}

Treatments consisted of two triploid hybrids from napier grass (Pennisetum purpureum Schumach.) and pearl millet (Pennisetum glaucum (L.) R. Br.), designated H1 (CNPGL 91-2-5x M42) and H2 (Merker Pinda x M42); three vegetative materials (leaves from seedlings cultured in vitro and in vivo, and calli); eight enzymatic solutions [cellulase R-10 (0.5, 1.0, 1.5 and 2.0\%) added of macerozyme $(0.2 \%)$ and driselase $(0.1 \%)$ or pectolyase Y-23 $(1.0 \%)$ and hemicellulase $(0.5 \%)]$; and different incubation times $(1,2,3,4$, and 5 hours).

The plant materials were taken from seedlings germinated in Plantmax ${ }^{\circledR}$ substrate in a greenhouse or germinated in vitro. For in vitro germination, seeds were disinfected with sulfuric acid $50 \%$ for 15 minutes and treated with alcohol solution $70 \%(\mathrm{v} / \mathrm{v})$ for 1 minute. Then, seeds were immersed in sodium hypochlorite solution $50 \%(\mathrm{v} / \mathrm{v})$ containing $2.5 \%$ active chlorine content during 15 minutes and washed three times with sterile distilled water in a laminar air-flow cabinet. Each seed was inoculated into a test tube containing $10 \mathrm{~mL}$ MS culture medium (Murashige \& Skoog, 1962) supplemented with $3 \%$ sucrose. Cultures were kept in a growth chamber at $26 \pm 2{ }^{\circ} \mathrm{C}$ with $16 \mathrm{~h}$ light $/ 8 \mathrm{~h}$ darkness and a total irradiance of $25 \mu \mathrm{mol} \mathrm{m} \mathrm{m}^{2} \mathrm{~s}^{-1}$ provided by cool-white fluorescent lamps. Assays for protoplast production were carried out after 30 days of in vivo or in vitro cultivation.

Callus culture was obtained from three-cm basal explants taken from in vitro cultured seedlings of triploid hybrids and transferred to containers $(250 \mathrm{~mL})$ with $30 \mathrm{~mL}$ of MS medium plus $2.0 \mathrm{mg} \mathrm{L}^{-1}$ of the plant growth regulator 2,4-D (dichlorophenoxyacetic acid). Cultures were maintained in a growth chamber at $26 \pm 2^{\circ} \mathrm{C}$ with $16 \mathrm{~h}$ light/ $8 \mathrm{~h}$ darkness and a total irradiance of $25 \mu \mathrm{mol} \mathrm{m} \mathrm{m}^{-1}$ provided by cool-white fluorescent lamps. For culture maintenance, calli were subcultivated in a new medium every 20 days, according to Passos \& Kattermain (1994).

Enzymatic solutions were prepared through dilution in CPW (cell protoplast wash) medium which contained $\mathrm{KH}_{2} \mathrm{PO}_{4}\left(27.2 \mathrm{mg} \mathrm{L}^{-1}\right), \mathrm{KNO}_{3}\left(101 \mathrm{mg} \mathrm{L}^{-1}\right), \mathrm{CaCl}_{2} \cdot 2 \mathrm{H}_{2} \mathrm{O}(1480$ $\left.\mathrm{mg} \mathrm{L}^{-1}\right), \mathrm{MgSO}_{4} .7 \mathrm{H}_{2} \mathrm{O}\left(246 \mathrm{mg} \mathrm{L}^{-1}\right), \mathrm{KI}\left(0.16 \mathrm{mg} \mathrm{L}^{-1}\right)$, and $\mathrm{CuSO}_{4} .5 \mathrm{H}_{2} \mathrm{O}\left(0.025 \mathrm{mg} \mathrm{L}^{-1}\right)$, according to Frearson et al. (1973), supplemented with mannitol 13\%. After $\mathrm{pH}$ adjustment to 5.6 with $5 \mathrm{mM} 2$-[N-morpholino]ethanesulphonic acid (MES), solutions were filter-sterilized in Millipore filter membranes of $0.22 \mu \mathrm{m}$ porosity.

The grass was planted in potting soil and kept inside the greenhouse. The primary explants were washed in running tap water for $30 \mathrm{~min}$. The foliar segments were disinfected in $70 \%$ (v/v) ethanol for $1 \mathrm{~min}$, immersed in $2.5 \%$ sodium hypochlorite solution for $10 \mathrm{~min}$, and washed three times with sterile distilled water.

The protoplasts were obtained from $500 \mathrm{mg}$ of in vivo and in vitro leaflets. Approximately 1-cm-long foliar segments were sliced into $1 \mathrm{~mm}$ strips. The plant material was then pre-plasmolized for 1 hour, in the absence of light, in $20 \mathrm{~mL} \mathrm{CPW}+$ mannitol $13 \%$.

Later, CPW + mannitol $13 \%$ solution was discarded using Pasteur pipettes and $20 \mathrm{~mL}$ of the enzymatic mixture was added. Each sample received different enzymatic treatments.

Protoplasts were obtained from calli by transferring $1 \mathrm{~g}$ plant material to a $10 \mathrm{~mL} \mathrm{CPW} \mathrm{+} \mathrm{mannitol} 13 \%$ solution, for 1 hour, in the dark, to allow pre-plasmolisis. At the end of this period, $10 \mathrm{~mL}$ concentrated enzymatic solution was added, resulting in a final volume of $20 \mathrm{~mL}$.

Enzymatic digestion occurred due to the 5-hour incubation of leaf and callus explants in the dark, at $40 \mathrm{rpm}$ agitation and $26 \pm 2^{\circ} \mathrm{C}$ temperature. It was monitored once every hour, when a little aliquot was taken from each plate/ treatment for protoplasts quantification under optical microscope in a Neubauer chamber. Evans blue stain at $0.05 \%$ was used to count viable protoplasts, i.e. those that excluded the stain.

\section{RESULTSAND DISCUSSION}

Protoplast yield was dependent on the employed plant material. Leaflets from plants cultured both in vivo and in vitro showed to be the best sources (Table 1 and Figure 1). 
Table 1 - Quantification of viable protoplasts (x $10^{4}$ ) produced from leaflets of seedlings cultured in vitro and in vivo and from calli of $\mathrm{H} 1$ and $\mathrm{H} 2$ triploid hybrids in different enzymatic solutions during five hours digestion.

\begin{tabular}{|c|c|c|c|c|c|c|c|c|c|c|c|}
\hline \multirow{2}{*}{\multicolumn{2}{|c|}{ TREATMENTS }} & \multicolumn{10}{|c|}{ HYBRIDS } \\
\hline & & \multirow{2}{*}{\multicolumn{2}{|c|}{$\begin{array}{l}\text { H1 H2 } \\
1 \text { hour }\end{array}$}} & \multirow{2}{*}{\multicolumn{2}{|c|}{2 hours }} & H1 & $\mathrm{H} 2$ & $\mathrm{H} 1$ & $\mathrm{H} 2$ & $\mathrm{H} 1$ & $\mathrm{H} 2$ \\
\hline & & & & & & \multicolumn{2}{|c|}{3 hours } & \multicolumn{2}{|c|}{4 hours } & \multicolumn{2}{|c|}{5 hours } \\
\hline \multirow{8}{*}{$\begin{array}{l}\text { In vitro } \\
\text { leaflets }\end{array}$} & $\mathrm{E} 1$ & 0 & 0 & 1.25 & 2.63 & 2.0 & 3.0 & 0.5 & 3.0 & 5.63 & 3.38 \\
\hline & E2 & 0 & 0 & 4.75 & 1.13 & 13.5 & 1.88 & 17.88 & 11.25 & 27.75 & 2.8 \\
\hline & E3 & 0 & 0 & 0.75 & 3.88 & 3.88 & 8.5 & 11.63 & 18.63 & 10.25 & 11.63 \\
\hline & E4 & 0 & 1.63 & 0.13 & 2.5 & 6.0 & 26.25 & 9.0 & 21.0 & 9.38 & 23.5 \\
\hline & E5 & 0 & 0 & 0.5 & 0 & 2.63 & 0 & 1.25 & 0 & 1.25 & 0.38 \\
\hline & E6 & 0 & 0 & 0.25 & 0 & 0.88 & 0 & 0.5 & 0 & 1.5 & 0.13 \\
\hline & E7 & 0 & 0 & 1.25 & 0 & 1.25 & 0 & 2.63 & 0.5 & 3.0 & 0 \\
\hline & E8 & 0 & 0 & 0.25 & 0 & 0.88 & 0 & 3.25 & 0.25 & 1.75 & 0.25 \\
\hline \multirow{8}{*}{$\begin{array}{l}\text { In vivo } \\
\text { leaflets }\end{array}$} & $\mathrm{E} 1$ & 0 & 0 & 0.13 & 0 & 0.13 & 0 & 0.25 & 0 & 0.63 & 0 \\
\hline & $\mathrm{E} 2$ & 0 & 0 & 1.0 & 0 & 0.75 & 0 & 2.38 & 0.10 & 2.38 & 1.0 \\
\hline & E3 & 0 & 0 & 0.63 & 0 & 0.5 & 0 & 0.25 & 0 & 1.0 & 0 \\
\hline & E4 & 0 & 0 & 0 & 0 & 0.13 & 0 & 0.25 & 0.15 & 1.38 & 1.50 \\
\hline & E5 & 0 & 0 & 0 & 0 & 0 & 0 & 0 & 0 & 0 & 1.0 \\
\hline & E6 & 0 & 0 & 0 & 0 & 0 & 0 & 0 & 0 & 0 & 1.0 \\
\hline & E7 & 0 & 0 & 0 & 0 & 0 & 0 & 0 & 0 & 0 & 0.20 \\
\hline & E8 & 0 & 0 & 0 & 0 & 0 & 0 & 0 & 0 & 0 & 0.20 \\
\hline Calli & E1-E8 & 0 & 0 & 0 & 0 & 0 & 0 & 0 & 0 & 0 & 0 \\
\hline
\end{tabular}

$\mathrm{H} 1=$ hybrid $1 ; \mathrm{H} 2=$ hybrid $2 ; \mathrm{E}=$ enzymatic solution; $\mathrm{E} 1=0.5 \%$ cellulase $\mathrm{R}-10,0.2 \%$ macerozyme and $0.1 \%$ driselase $; \mathrm{E} 2=1.0 \%$ cellulase R-10, $0.2 \%$ macerozyme and $0.1 \%$ driselase; $\mathrm{E} 3=1.5 \%$ cellulase $\mathrm{R}-10,0.2 \%$ macerozyme and $0.1 \%$ driselase; $\mathrm{E} 4=2.0 \%$ cellulase R-10, $0.2 \%$ macerozyme and $0.1 \%$ driselase; E5 $=0.5 \%$ cellulase R-10, $1.0 \%$ pectinase and $0.5 \%$ hemicellulase; E6 = $1.0 \%$ cellulase $\mathrm{R}-10,1.0 \%$ pectinase and $0.5 \%$ hemicellulase; $\mathrm{E} 7=1.5 \%$ cellulase $\mathrm{R}-10,1.0 \%$ pectinase and $0.5 \%$ hemicellulase and $\mathrm{E} 8=2.0 \%$ cellulase R-10, $1.0 \%$ pectinase and $0.5 \%$ hemicellulase. Obtained yield $\mathrm{x} 10^{4}$ protoplasts $\mathrm{mL}$.

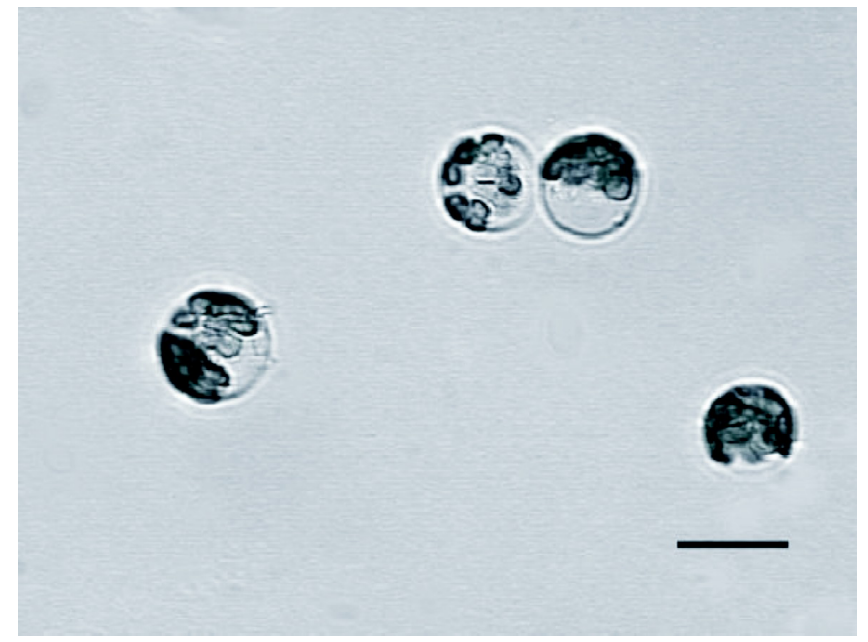

Figure 1 - Viable protoplasts from in vitro leaflet tissue of $\mathrm{H} 2$ triploid hybrid between napier grass and pearl millet using the enzymatic solution $\mathrm{E} 4$. Bar $=50 \mu \mathrm{m}$. 
The maximum protoplast yield for both hybrids was obtained from in vitro leaflets: $27.75 \times 10^{4}$ protoplasts/mL for $\mathrm{H} 1$ hybrid after 5 hours digestion in the enzymatic solution E2 (1.0\% cellulase R-10, $0.2 \%$ macerozyme and $0.1 \%$ driselase), and $26.25 \times 10^{4}$ protoplasts/mL for $\mathrm{H} 2$ hybrid after 3 hours digestion by the enzymatic solution E4 (2.0\% cellulase R-10, $0.2 \%$ macerozyme and $0.1 \%$ driselase).

Prasertsongskum (2004) also obtained the best result $\left(8.4 \times 10^{4}\right.$ protoplasts $\left./ \mathrm{mL}\right)$ with the grass Vetiveria zizanioides (L.) Nash when cellulase and macerozyme were present in the enzymatic solution ( $2.0 \%$ cellulase R-10 plus $2.0 \%$ macerozyme and $0.5 \%$ pectinase).

For both hybrids, the highest efficiency in cell wall digestion was achieved with the combination among cellulase R-10, macerozyme and driselase enzymes. Leaflets from seedlings cultured under in vitro conditions were softer, smaller and thinner than those from in vivo cultivation, which favored the enzymatic action. These morphological differences were probably due to the lower light intensity and higher humidity under in vitro conditions.

Similar results were reported by Komai et al. (1996), who obtained $1.46 \times 10^{7}$ protoplasts/g leaves when spinach (Spinacia oleracea L.) seedlings cultured in vitro were treated from 4 to 10 hours with $2 \%$ cellulase R-10 and $0.5 \%$ macerozyme R-10. Hu et al. (1999) also used the enzymatic solution of $2 \%$ cellulase R-10, $1.0 \%$ macerozyme, $0.5 \%$ driselase, between 15 and 20 hours, to isolate protoplasts from in vitro leaves and hypocotyl of several Brassica species.

Although at a small quantity, protoplasts were obtained from leaflets of in vivo-cultured seedlings. It is interesting to note, however, that in $\mathrm{H} 1$ and $\mathrm{H} 2$ hybrids the maximum protoplast yield from both in vitro and in vivo explants was observed under the same enzymatic treatment. For H1, E2 treatment allowed the production of only $2.38 \times 10^{4}$ protoplasts $/ \mathrm{mL}$ after five hours of digestion, whereas in vitro leaflets had a 12-fold higher yield $\left(27.75 \times 10^{4}\right.$ protoplasts $\left./ \mathrm{mL}\right)$. As regards $\mathrm{H} 2$, the best enzymatic solution was E4, with which $1.5 \times 10^{4}$ protoplasts $/ \mathrm{mL}$ were obtained after five hours digestion of in vivo leaflets, whereas only three hours digestion of in vitro leaflets were needed to achieve approximately 18 -fold higher yield (26.25 x 104 protoplasts/mL) (Table 1).

Calli showed not to be a good vegetative material to produce protoplasts from $\mathrm{H} 1$ and $\mathrm{H} 2$ hybrids.

Vasil et al. (1983) isolated protoplasts from cell suspensions originated from calli of napier grass (Penisetum purpureum Schumach.) inflorescences.
After extensive work, they concluded that the best enzymatic treatment included $2.5 \%$ cellulase R-10, with or without $1.0 \%$ macerozyme, which allowed the isolation of $80 \%$ protoplasts after six hours digestion.

It must be emphasized that protoplast yield varies significantly in the different studies available in the literature. This is mainly due to the plant material cultivation method and to the production conditions besides other several factors, such as the genotype as well as the enzymatic combinations and concentrations employed in the study.

\section{CONCLUSIONS}

Leaflets from seedlings cultured in vitro were the best sources to produce protoplasts from napier grass and pearl millet triploid hybrids.

The enzymatic combination among cellulase, macerozyme and driselase led to higher protoplast yield for both studied hybrids.

\section{ACKNOWLEDGEMENTS}

The authors wish to thank FAPEMIG for financial support, Capes for Master's scholarship to the first author, CNPq for productivity scholarship, and Prof. Wagner Campos Otoni for his valuable suggestions.

\section{REFERENCES}

ABREU, J.C.; DAVIDE, L.C.; PEREIRA, A.V.; BARBOSA, $\mathrm{S}$. Mixoploidia em híbridos de capim-elefante $\mathrm{x}$ milheto tratados com agentes antimitóticos. Pesquisa

Agropecuária Brasileira, Brasília, v.41, n.11, p.1629$1635,2006$.

BARBOSA, S.; DAVIDE, L.C.; PEREIRA, A.V.; ABREU, J.C. Duplicação cromossômica de híbridos triplóides de capim-elefante e milheto. Bragantia, Campinas, v.66, n.3, p.365-372, 2007.

FREARSON, E.M.; POWER, J.B.; COCKING, E.C. The isolation, culture and regeneration of Petunia leaf protoplast. Developmental Biology, Orlando, v.33, p.130137, 1973.

HANNA, W.W. Melhoramento do capim-elefante. In: PASSOS, L.P.; CARVALHO, L.A.; MARTINS, C.E.; PEREIRA, A.V. (Eds.). Biologia e manejo do capim-elefante. Juiz de Fora: Embrapa Gado de Leite, 1999. p.17-28.

HANNA, W.W. Method of reproduction in napiergrass and in the $3 \mathrm{X}$ and $6 \mathrm{X}$ alloploid hybrids with pearl millet. Crop Science, Madison, v.21, p.123-126, 1981. 
HANNA, W.W.; GAINES, T.P.; GONZALEZ, B.; MONSON, W.G. Effect of ploidy on yield and quality of pearl millet x napier grass hybrids. Agronomy Journal, Madison, v.76, n.6, p.969-971, 1984.

HU, Q.; ANDERSEN1, S.B.; HANSEN, L.N. Plant regeneration capacity of mesophyll protoplasts from Brassica napus and related species. Plant Cell, Tissue and Organ Culture, Dordrecht, v.59, p.189196, 1999.

JAUHAR, P.P.; HANNA, W.W. Cytogenetics and genetics of pearl millet. Advances Agronomy, New York, v.64, p.1-26, 1998.

KOMAI, F.; MASUDA, K.; HARADA, T.; OKUSE, I. Plant regeneration from adventitious roots of spinach (Spinacia oleracea L.) grown from protoplasts. Plant Science, Shannon, n.120, p.89-94, 1996.

MESA-PEREZ, J.M.; CORTEZ, L.A.B.; ROCHA, J.D.; BROSSARD-PEREZ, L.E.; OLIVARES-GOMEZ, E. Unidimensional heat transfer analysis of elephant grass and sugar cane bagasse slow pyrolysis in a fixed bed reactor. Fuel Processing Technology, Amsterdam, v.86, p.565-575, 2005.

MURASHIGE, T.; SKOOG, F. A revised medium for rapid growth and bio assays with tobacco tissue cultures. Physiology Plant, Bethesda, v.15, p.473-497, 1962.

PASSOS, L.P.; KATTERMAN, F. Produção de calos embriogênicos em capim-elefante, em resposta a diferentes cultivos, explantes e reguladores de crescimento. Revista da Sociedade Brasileira de Zootecnia, Viçosa, v.23, n.5, p.743-753, 1994.
PEREIRA, A.V.; VALLE, C.B.; FERREIRA, R.P.; MILES, J.W. Melhoramento de forrageiras tropicais. In: NASS, L.L.; VALOIS, A.C.C.; MELO, I.S.; VALADARES-INGLIS, M.C. Recursos genéticos e melhoramento.

Rondonópolis: Fundação Mato Grosso, 2001. p.549-602.

PRASERTSONGSKUN, S. Isolation and culture of suspension protoplasts of vetiver. Songklanakarin Journal of Science and Technology, Songkhla v.26, n.3, p.411-416, 2004.

SCHANK, S.C.; DIZ, D.A.; WOFFORD, D.S. Seed production on detached culms of pearl millet $\times$ elephantgrass hexaploid hybrids. HortScience, Alexandria, v.31, n.5, p.827-828, 1996.

SOUZA SOBRINHO, F.; LEDO, F.J.S.; PEREIRA, A.V.; OLIVEIRA, J.S. Avaliação do potencial de propagação por sementes de capim-elefante hexaplóide. Ciência e Agrotecnologia, Lavras, v.32, n.3, p.974-977, 2008.

STREZOV, V.; EVANS, T.J.; HAYMAN, C. Thermal conversion of elephant grass (Pennisetum Purpureum Schum) to bio-gas, bio-oil and charcoal. Bioresource Technology, New York, v.99, n.17, p.8394-8399, 2008.

VASIL, V.; WANG, D.; VASIL, I.K. Plant Regeneration from protoplasts of Napier Grass (Pennisetum purpureum Schum.). Zeitschrift für

Pflanzenphysiologie, Stuttgart, v.111, p.233-239, 1983.

ZENG, S.H.; CHUAN-WU, C.; LUI, H.; JI-HONG, L.; XIUXIN, D. In vitro indução, regeneration and analysis of autotetraploids derived from protoplasts and callus treated with colchicine in Citrus. Plant Cell Tiss Organ Cult, Netherlands, v.87, p.85-93, 2006. 